\title{
Enhancement of Crude Oil Biodegradation by Immobilizing of different Bacterial Strains on Porous PVA Hydrogels or Combining of them with their produced Biosurfactants
}

\author{
Abdeen $\mathrm{Z}^{1 *}$, Huda K El-Sheshtawy ${ }^{2}$ and Moustafa $\mathrm{YMM}^{3}$ \\ ${ }^{1}$ Petrochemical Department, Egyptian Petroleum Research Institute, Nasr City, Cairo, Egypt \\ ${ }^{2}$ Processes Development Department, Egyptian Petroleum Research Institute, Nasr City, Cairo, Egypt \\ ${ }^{3}$ Evaluations and Analysis Department, Egyptian Petroleum Research Institute, Nasr City, Cairo, Egypt
}

\begin{abstract}
The degradation of the crude oil in wastewater by each of freely microorganisms and by immobilized them on each of crosslinked poly (vinyl alcohol) hydrogel (CPVA) and its foam (CPVAF) was reported. Also, it was studied by using biosurfactants ( $\mathrm{Bio}$ ) with free cells. The macroporous CPVAF was prepared by adding $\mathrm{CaCO}_{3}$ as poreforming agent and epichlorohydrin as crosslinker. The prepared polymers are examining by FTIR, XRD, TGA, DSC and SEM analysis. The microorganisms of B.I., R.e. and P.x. isolated from contaminated effluents were investigated. The ability of these microorganisms to degrade the n-paraffin and PAHs was assessed by GC and HPLC analysis, respectively. Moreover, their stabilities and activities were tested in the growth count of bacteria study. The crosslinked CPVA carrier demonstrated better thermal stability and improvement in the microorganism efficiency with respect to hydrocarbons degradation than these of the CPVAF carrier. Scanning electron microscopy showed the presence of extracellular structures that could play an important role in the immobilization stability of cells on polymers. As well, GC analysis revealed that the percentage biodegradation ability of immobilized cells R.e. on CPVAF for the total n-paraffin was approximately, $100 \%$. While, the HPLC analysis showed that the percentage biodegradation of cells for PAHs was enhancement by immobilized them on CPVA and also, at adding Bio to them. The results suggest that the potential of using each of CPVA, PVAF as cell carriers and Bio separately, to free cells to enhancing the biodegradation of petroleum hydrocarbons in an open marine environment.
\end{abstract}

Keywords: Immobilization; Crosslinked poly (vinyl alcohol) hydrogel; Foam; Biodegradation; Biosurfactants; Hydrocarbons.

\section{Introduction}

Biodegradation of petroleum hydrocarbons is a complex process that depends on the nature and the amount of the hydrocarbons present, saturates, aromatics, asphaltenes and the polar compounds [1]. The polycyclic aromatic hydrocarbons (PAHs) [2] are a minor constituent of crude oils; however, they are widespread environmental pollutants. They are generated from petroleum and many pyrolysis processes. They form concern because of their potentially deleterious effects on human health and many can be recalcitrant in the environment [3]. Bioremediation can be described as the conversion of chemical compounds by living organisms, especially microorganisms, into energy, cell mass and biological waste products [4]. Bacteria can convert PAHs completely to biomass, $\mathrm{CO}_{2}$, and $\mathrm{H}_{2} \mathrm{O}$. A wide range of different bacteria is able to completely assimilate a defined range of compound, or exhibit just partial metabolism [5]. Therefore, the use of pure cultures of microorganisms, specially adapted to metabolize the contaminant, is envisaged as an attractive alternative. Rhodococcus erythropolis is well known microorganism containing a large set of enzymes that allows carrying out an enormous number of bioconversion and degradation [6,7]. Biosurfactants are biological compounds that exhibit high surface-active properties [8] and are produced by a wide variety of microbes. Wide spectra of microbial compounds, including glycolipids, lipopeptides, fatty acids, and polymeric biosurfactants, have been found to have surface activity [9]. They have important advantages, such as biodegradability, low toxicity, and various possible structures, relative to chemically synthesized surfactants [10]. So, they were use in environmental applications, such as in bioremediation [11] and in enhanced oil recovery [12]. Microbial cells can be immobilized on various hydrophilic polymeric entrapment matrices such as hydrogels
[13]. Among hydrophilic polymers, poly (vinyl alcohol) PVA, poly (hydroxyethylmetacrylate) PHEMA and others, are the most often used for hydrogel's synthesis [14-17]. Poly (vinyl alcohol) (PVA) is a water-soluble material that has been widely used for immobilization of bioactive materials [18]. Because of, PVA is innocuous for bioactive matter and possesses many attractive properties [19], it is a potential bio-carrier material that can be applied in the fermentation industry [20], chemistry [21], and the environment [22]. The chemical stability and mechanical properties can be improved by physical or chemical crosslinking [19]. Nevertheless, research on the preparation and use of PVA foam for microbial immobilization is rarely reported. Therefore, there is a great scope for designing better PVA foam carriers for immobilizing microorganisms and developing new technologies for wastewater bio-treatment. In this work, hydrogel composites based on PVA and calcium carbonate were prepared and foamed by adding hydrochloric acid, to produce a macroporous carrier [23]. Epichlorohydrin was then used as a chemical crosslinking agent to form network structures as well as to improve the foam's stability. Further investigation has revealed the desirable properties of crosslinked

*Corresponding author: Abdeen Z, Petrochemical Department, Egyptian Petroleum Research Institute, Nasr City, Cairo, Egypt, Tel: 20 1154459620; E-mail: ziziabdeen@yahoo.com

Received August 30, 2014; Accepted October 01, 2014; Published October 17, 2014

Citation: Abdeen Z, El-Sheshtawy HK, Moustafa YMM (2014) Enhancement of Crude Oil Biodegradation by Immobilizing of different Bacterial Strains on Porous PVA Hydrogels or Combining of them with their produced Biosurfactants. J Pet Environ Biotechnol 5: 192. doi:10.4172/2157-7463.1000192

Copyright: @ 2014 Abdeen Z, et al. This is an open-access article distributed under the terms of the Creative Commons Attribution License, which permits unrestricted use, distribution, and reproduction in any medium, provided the original author and source are credited. 
Citation: Abdeen Z, El-Sheshtawy HK, Moustafa YMM (2014) Enhancement of Crude Oil Biodegradation by Immobilizing of different Bacterial Strains on Porous PVA Hydrogels or Combining of them with their produced Biosurfactants. J Pet Environ Biotechnol 5: 192. doi:10.4172/21577463.1000192

PVA foam (CPVAF) as a carrier of immobilized microorganisms. A crosslinked prepared PVA (CPVA) carrier was chosen for comparison and it was used for the preparation of the immobilization matrix. The main advantages in the use of immobilized cells in comparison with suspended ones include the retention in the reactor of higher concentration of microorganisms, easy removal of bacteria after use from the reaction mixture, providing the ability to control reaction time, reuse of cells for many reaction cycles, lowering the total production cost of cells-mediated reactions, provide pure products [24-26]. The efficiencies of each of free, immobilized cells (Bacillus licheniformis, Rhodococcuserythropolishas and Pseudomonas xanthomarina) on CPVAF and CPVA matrixes crosslinked by epichlorohydrin [17], and their biosurfactants in degradation of crude oil in water were evaluated. In addition, we evaluated the capability of each of CPVA and CPVAF in water, as immobilizers to the enhancement the degradation efficacy of each microorganism to degrade the pollutants.

\section{Materials and Methods}

\section{Materials and microorganism}

The PVA used in this study was analytical grade and was purchased from Merck, Germany. The average $M_{w}$ of the PVA was 127,000 and the degree of hydrolysis was $89 \%$. Epichlorohydrin (EP), calcium carbonate, sodium hydroxide, hydrochloric acid and other chemicals were all obtained from Beijing Chemical Reagent Factory (China) and used without further purification. The crude oil used in the present work, was Asphaltenic crude oil. The microorganisms used in this study were, Bacillus licheniformis ATCC10716 (B.l.) and Rhodococcus erythropolis ATCC13260 (R.e.) supplied by the microbial resources center (MIRCEN), Faculty of Agriculture, Ain Shams University, Cairo, Egypt. Also, Pseudomonas xanthomarina KMM 1447 (P.x.) bacterial was isolated from Gemsa Bay (Red Sea).

\section{Molecular identification of the bacterial strain isolated from the Red Sea}

An analysis of 16S rRNA was performed to taxonomically characterize the isolated strains (Sigma Scientific Services Co., Egypt). The cell of the bacterial strain was harvested through the enrichment medium up to $2 \times 10^{9}$ bacterial cells. DNA was extracted using protocol of Gene Jet genomic DNA purification Kit (Thermo) (Sigma Scientific Services Co., Egypt). To amplify the $16 \mathrm{~S}$ rDNA gene, a polymerase chain reaction (PCR) was performed using two primers, the forward primer (5'-AGA GTT TGA TCC TGG CTCA-3') and the reverse primer (5'-GGT TAC CTT GTT ACG ACT-3'). PCR was cleaned up to the PCR product using GeneJET ${ }^{\mathrm{Tx}}$ PCR Purification Kit. A $45 \mathrm{ul}$ of Binding Buffer was added to completed PCR mixture. The mixture was then thoroughly, transferred from step 1 to the GeneJET ${ }^{\mathrm{m} w}$ purification column. The mixture was centrifugated for $30-60 \mathrm{~s}$ at $>12000 \mathrm{x} \mathrm{g}$, then the flow were discarded. A $100 \mathrm{ul}$ of wash buffer was added to the GeneJET ${ }^{\mathrm{Tw}}$ purification column and centrifuged for 30-60 s. Then, discarded the flow-through and placed the purification column back into the collection tube. The mixture was centrifugated the empty GeneJET $^{\mathrm{mit}}$ purification column for an additional one min. to completely remove any residual wash buffer. The purification column was transferred to a clean $1.5 \mathrm{ml}$ micro centrifuge tube. A $25 \mathrm{ul}$ of elution buffer was added to the center of the GeneJET ${ }^{\mathrm{Tx}}$ purification column membrane and centrifuged for one min. The GeneJET ${ }^{\mathrm{Tax}}$ purification column was discarded and the purified DNA was stored at $-20^{\circ} \mathrm{C}$. Following purification of the PCR products, the DNA sequence of the positive clone was subjected to a similarity search BLAST on the NCBI website (http://www.ncbi.nlm.nih.gov), and deposited into GenBank.
Many relevant $16 \mathrm{~S}$ rRNA gene sequences with validly published names were selected as references from the Gen- Bank.

\section{Culture conditions}

Culture medium and production of different biosurfactants: The bacterial strains were streaked on a nutrient agar slants and incubated for $24 \mathrm{~h}$ at $30^{\circ} \mathrm{C}$. Two loops of each culture were inoculated in $40 \mathrm{ml}$ of nutrient broth in a $100 \mathrm{ml}$ Erlenmeyer flask and incubated in a rotary shaker $150 \mathrm{rpm}$ at $30^{\circ} \mathrm{C}$ for $8-12 \mathrm{~h}$ until cell numbers reached $10^{8} \mathrm{CFU} / \mathrm{ml}$. For biosurfactant synthesis, a mineral salt medium with the following composition was utilized: $2.0 \mathrm{~g} / \mathrm{l}$ of $\mathrm{Na}_{2} \mathrm{HPO}_{4}, 2.0 \mathrm{~g} / \mathrm{l}$ of $\mathrm{KH}_{2} \mathrm{PO}_{4}, 0.01 \mathrm{~g} / \mathrm{l}$ of $\mathrm{MgSO}_{4} .7 \mathrm{H}_{2} \mathrm{O}, 2.5 \mathrm{~g} / \mathrm{l}$ of $\mathrm{NaNO}_{3}, 0.8 \mathrm{~g} / \mathrm{l}$ of $\mathrm{NaCl}$, $0.2 \mathrm{~g} / \mathrm{l}$ of $\mathrm{CaCl}_{2}, 0.8 \mathrm{~g} / \mathrm{l}$ of $\mathrm{KCl}, 0.001 \mathrm{~g} / \mathrm{l}$ of $\mathrm{FeSO}_{4} .7 \mathrm{H}_{2} \mathrm{O}$ and $5 \mathrm{ml}$ of a trace element solution. Trace element solution contained $0.116 \mathrm{~g} / \mathrm{l}$ of $\mathrm{FeSO}_{4} \cdot 7 \mathrm{H}_{2} \mathrm{O}, 0.232 \mathrm{~g} / \mathrm{l}$ of $\mathrm{H}_{3} \mathrm{BO}_{3}, 0.41 \mathrm{~g} / \mathrm{l}$ of $\mathrm{CoCl}_{2} \cdot 6 \mathrm{H}_{2} \mathrm{O}, 0.008 \mathrm{~g} / \mathrm{l}$ of $\mathrm{CuSO}_{4} \cdot 5 \mathrm{H}_{2} \mathrm{O}, 0.008 \mathrm{~g} / \mathrm{l}$ of $\mathrm{MnSO}_{4} \cdot \mathrm{H}_{2} \mathrm{O}, 0.022 \mathrm{~g} / \mathrm{l}$ of $\left[\mathrm{NH}_{4}\right]_{6} \mathrm{Mo}_{7} \mathrm{O}_{24}$ and $0.174 \mathrm{~g} / \mathrm{l}$ of $\mathrm{ZnSO}_{4}$ [27]. The carbohydrate (glucose) was added to make a final concentration $2 \%$, and the concentration of yeast extract was $3 \%$. Cultivation studies have been done in $500 \mathrm{ml}$ flasks containing $150 \mathrm{ml}$ medium at $30^{\circ} \mathrm{C}$ for $72 \mathrm{~h}$.

\section{Preparation of PVA hydrogel crosslinked by epichlorohydrin (CPVA) [16]}

CPVA was prepared by adding PVA to $100 \mathrm{ml}$ of distilled water and blending by a mechanical stirrer in a boiling water bath for $1 \mathrm{~h}$. After the mixture cooled to room temperature, stoichiometric amounts of each of epichlorohydrin (EP) as the crosslinker and potassium hydroxide solution were added separately to the mixture with stirring it gently, at $35^{\circ} \mathrm{C}$ for $2 \mathrm{~h}$. The amount ratios of PVA/E/KOH were: $100 / 20 / 25$, $100 / 60 / 65,100 / 100 / 105$ and 100/125/130, 100/140/150. Five CPVA hydrogel disc samples were prepared.

\section{Preparation of crosslinked PVA hydrogel foam (CPVAF)}

CPVAF was prepared as follows: calcium carbonate powder and PVA were added in ratio 1:2 to $100 \mathrm{ml}$ distilled water and blended by a mechanical stirrer in a boiling water bath for $1 \mathrm{~h}$. After the mixture cooled to room temperature, the certain amount of hydrochloric acid (5 M) was added and the mixture was stirred vigorously to dissolve the calcium carbonate and produce $\mathrm{CO}_{2}$ gas bubbles. Then the molded foam was submerged in $200 \mathrm{ml} \mathrm{NaOH}(1 \mathrm{M})$ containing $1 \mathrm{ml}$ of EP and stirred gently at $35^{\circ} \mathrm{C}$ for $2 \mathrm{~h}$. All prepared CPVA and CPVAF gels were cut into discs of about $0.5 \mathrm{~cm}$ thickness and $1.2 \mathrm{~cm}$ diameter and maintained in sterile conditions until their use for cell immobilization [24].

\section{Biodegradation test of the crude oil using free cells in presence/ absence of different biosurfactants and by immobilizing of these cells on (CPVA and CPVAF) gels}

To assess the efficiency of different bacterial strains to degrade the crude oil, $2 \mathrm{ml}$ of inoculum ( $7.5 \mathrm{log}$ count) was inoculated into the medium mineral salt medium MSM $(100 \mathrm{ml})$ in a $250 \mathrm{ml}$ erlenmeyer flask. The cultures were incubated in a temperature controlled shaker incubator at $150 \mathrm{rpm}$ at $30^{\circ} \mathrm{C}$ for 15 days, using ( $1 \mathrm{~g}$ ) crude petroleum oil as a sole carbon source with/ without adding the discs of CPVA and CPVAF gels separately. The biosurfactant was produced by using the medium MSM with (1g) glucose as a sole carbon source for 72 $\mathrm{h}$ followed by addition of $(1 \mathrm{~g})$ crude oil until the end of incubation period. A sample without inoculum was taken as a control. Hence, the flasks were incubated at $30^{\circ} \mathrm{C}, 150 \mathrm{rpm}, \mathrm{pH} 7.5$ for 15 days [28]. After incubation period, the bacterial count was determined and the crude 
Citation: Abdeen Z, El-Sheshtawy HK, Moustafa YMM (2014) Enhancement of Crude Oil Biodegradation by Immobilizing of different Bacterial Strains on Porous PVA Hydrogels or Combining of them with their produced Biosurfactants. J Pet Environ Biotechnol 5: 192. doi:10.4172/21577463.1000192

oil samples were extracted from different microcosm and gravimetric analysis was also determined as follow:

Determination of the growth counts for different bacterial in presence/ absence biosurfactant and at immobilized these bacterial on CPVA and CPVAF gels: The bacterial counts were implemented by using the plate count technique where the different microcosms samples $(1 \mathrm{ml})$ was serially diluted in a sterile saline. Then inoculation in Luria broth (LB) plates medium containing ( $\mathrm{g} / \mathrm{l}$ of distilled water), $10.0 \mathrm{~g} / \mathrm{l}$ of $\mathrm{NaCl}, 10.0 \mathrm{~g} / \mathrm{l}$ of tryptone and $5.0 \mathrm{~g} / \mathrm{l}$ of extracted yeast, the medium was adjusted to $\mathrm{pH}$ 7.0. The cultures were then incubated at $30^{\circ} \mathrm{C}$ for $48 \mathrm{~h}$, then; the plate count in the range 30-300 Calonies was recorded. The bacterial count /ml (average colony forming unit (CFU)/ $\mathrm{ml}$ ) was calculated from the following equation:

Bacterial count / $\mathrm{ml}=$ colony count / plate $\mathrm{x}$ dilution factor [29].

Gravimetric estimation for the extracted crude oil after its biodegradation: After incubating period (15 days), the polluted bacterial broth $(100 \mathrm{ml})$ was thoroughly shaken with carbon tetrachloride $(50 \mathrm{ml}$ 3 times) in a separating funnel and the three fractions were collected in case of crude oil samples. The collected organic layer was dried over anhydrous sodium sulphate and the solvent was removed by a rotary evaporator till reached a constant weight. The oil sample was accurately weighed, the percentage of the biodegradation oil was calculated and the alteration in its chemical composition was studied by chromatographic analysis (GC and HPLC) [2,30].

\section{Characterization of CPVA and CPVAF hydrogels}

The structures of carriers CPVA and CPVAF were characterized before and after foaming, by using the FT-IR spectra that, recorded using a Nicolet IS-10 FT-IR spectrophotometer. Also, the thermal stabilities of the CPVA and CPVAF carriers were studied using a Thermogravimetric analyzer (TGA) and Differential scanning calorimetry (DSC). All TGA spectra were recorded under a nitrogen atmosphere up to $600^{\circ} \mathrm{C}$ using a programmed rate of $10^{\circ} \mathrm{C} / \mathrm{min}$ and the DSC spectra were obtained with a DSC-30 under $\mathrm{N}_{2}$ atmosphere at a heating rate of $20^{\circ} \mathrm{C} / \mathrm{min}$. X-ray diffraction patterns were recorded on X' Pert (Berlin, Germany) D500 diffract meter with a back monochromatic and a $\mathrm{Cu}$ anticathode. The phase morphology was studied using a JSM-T20 (JEOL, Tokyo, Japan) scanning electron microscope (SEM). For scanning electron observations, the surface of the sample was mounted on a standard specimen stub. A thin coating $\left(\sim 10^{-6} \mathrm{~m}\right)$ of gold was deposited into the sample surface and attached to the stub prior to SEM examination in the microscope to avoid electrostatic charging during examination. The Swelling behavior of the prepared hydrogels was estimated by immersing a known weight of the sample disc in solutions of $\mathrm{pH} 7$ at $30^{\circ} \mathrm{C}$ until the swelling equilibrium was reached. The disc was removed, dried with absorbent paper to get rid of excess water then weighed. The degrees of swelling (DS) for these samples were calculated at time intervals $(5,15,30,60,120,180$ minutes) with respect to CPVA (A) and CPVAF (B) samples, with the following equation:

$$
\mathrm{DS}=\left(\mathrm{m}-\mathrm{m}^{\prime}\right) / \mathrm{m}^{\prime}(1) \text {, }
$$

Where $\mathrm{m}$ and $\mathrm{m}$ ' denote the weights of hydrogel and dried hydrogel sample, respectively [31].

\section{Gas chromatographic analysis}

Biodegradation of the crude oil was monitored using an Agilent $6890^{+}$gas chromatography instrument according to the testing method IP 318 [32]. The detector was a flame ionization detector $325^{\circ} \mathrm{C}$, separation was completed on HP-1 capillary column (100\% methyl silicone siloxane, $30 \mathrm{~m}$ length, $0.35 \mathrm{~mm}$ internal diameter and $0.25 \mathrm{~mm}$ thickness film), a dose of $0.5 \mu \mathrm{l}$ was used using a splitter injector $300^{\circ} \mathrm{C}$ and the oven temperature $100-320^{\circ} \mathrm{C}$ reached applying a heating rate of $5^{\circ} \mathrm{C} / \mathrm{min}$. The carrier gas was nitrogen $(2 \mathrm{ml} / \mathrm{min})$. Identification of the $\mathrm{n}$-paraffins peaks was confirmed by chromatography a reference mixture of n-paraffins of a known composition under the same operating conditions.

\section{High performance liquid chromatographic (HPLC) analysis} [33]

The Identification and quantification of PAHs in the crude oil remained after biodegradation and the corresponding control sample were performed using HPLC. The apparatus used was model Waters HPLC 600 E, equipped with dual UV absorbance detector, model Waters 2487 and auto-sample Waters 717 plus attached to computerized system with millennium 3.2 soft ware. The condition of separation [34] is as follow: Column (Supelcosil.LC-PAH, $5 \mu \mathrm{m}$ particles, $15 \mathrm{~cm}$ length and $4.6 \mathrm{~mm}$ internal diameter), Mobile phase (gradient acetonitrile: water 60 to $100 \%$ acetonitrile (v/v) over 45 minutes), Flow rate (0-2 min. $0.2 \mathrm{ml} / \mathrm{min}, 2-45 \mathrm{~min} .1 .0 \mathrm{ml} / \mathrm{min}$ ) and Dector (Set at $254 \mathrm{~nm}$ ).

\section{Results and Discussions}

\section{Hydrogels characterization}

PVA contributed to strength and durability of the carriers. To get high strength, the percentage of PVA in the experiment was $10 \%$ concentrations, the higher than $10 \%$ resulted viscous solutions [15]. The amounts and the ratio of the pore-forming agents are the important factors which decide the aperture uniformity and size distribution, and the elasticity of the foams. The infrared spectra of PVA crosslinked (CPVA) [16] and crosslinked PVA foam (CPVAF) are represented in Figure $1 \mathrm{~A}$ and $1 \mathrm{~B}$, respectively. FTIR spectra shows broad peak at 3440 to $3100 \mathrm{~cm}^{-1}$ reveals stretching vibrations of the hydroxyl groups and the peak at 2940 to $2900 \mathrm{~cm}^{-1}$ is due to $\mathrm{C}-\mathrm{H}$ stretching vibrations. The CPVA spectra shows abroad bonded hydroxyl peak around $3263 \mathrm{~cm}^{-1}$, but the hydroxyl peak of CPVAF was obviously less condensed broad, and was shifted to $3313 \mathrm{~cm}^{-1}$. The intramolecular and intermolecular hydrogen bonds of the $\mathrm{OH}$ groups of PVA and other molecule, shifted the band of $-\mathrm{OH}$ group to lower frequencies as shown in spectra of CPVA .The $\mathrm{CaCO}_{3}$ shows absorption bands at 1419,871 and $713 \mathrm{~cm}$ ${ }^{1}$, which are attributed to the $\mathrm{Ca}-\mathrm{O}$ Stretching vibration and bending vibration. This result shows that network structures were formed on the

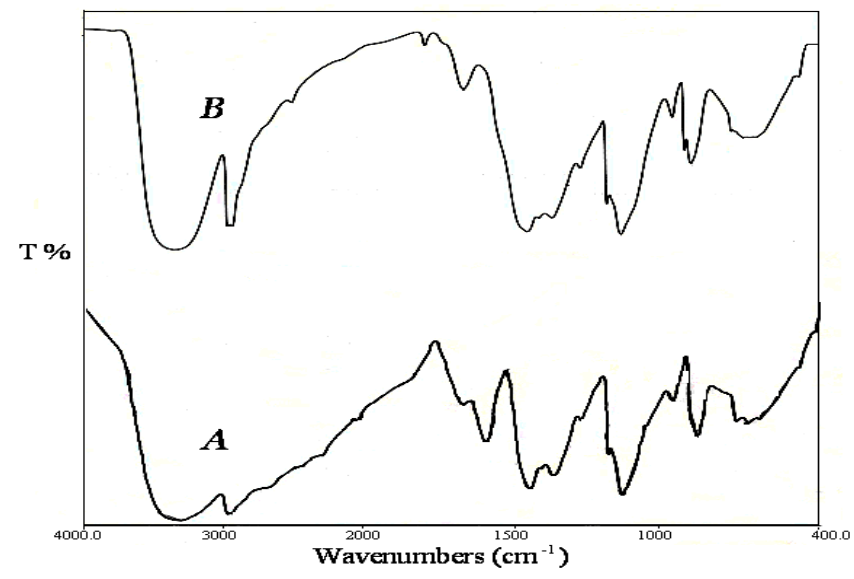

Figure 1: FT-IR spectra of CPVA (A) and CPVAF (B) carriers. 
Citation: Abdeen Z, El-Sheshtawy HK, Moustafa YMM (2014) Enhancement of Crude Oil Biodegradation by Immobilizing of different Bacterial Strains on Porous PVA Hydrogels or Combining of them with their produced Biosurfactants. J Pet Environ Biotechnol 5: 192. doi:10.4172/21577463.1000192

Page 4 of 10

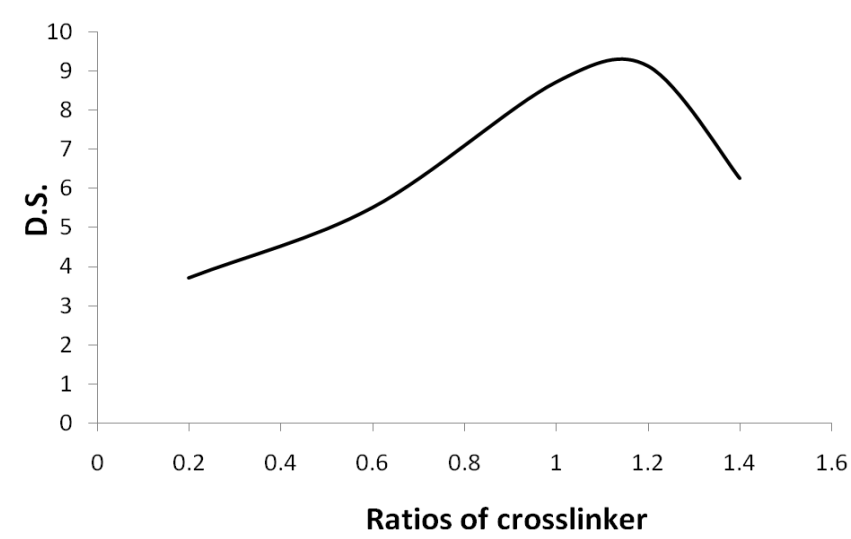

Figure 2: The degree of swelling (D.S) of CPVA at different ratios of crosslinker.

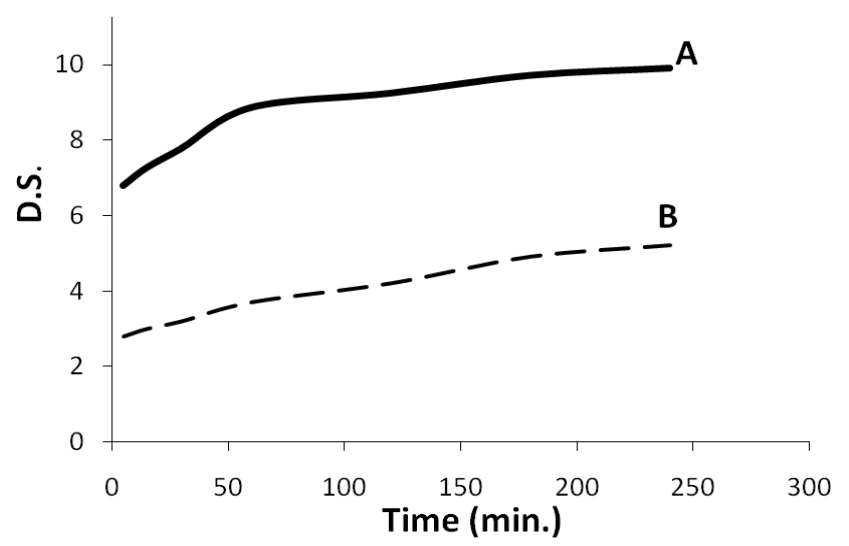

Figure 3: Swelling ratio of CPVA (A) and CPVAF (B) as a function of incubation time at $\mathrm{pH}=7$.

chains of the CPVA with a certain amount of hydroxyl. The stronger peak of CPVA and CPVAF carriers were at $1090 \mathrm{~cm}^{-1}(\mathrm{C}-\mathrm{O}-\mathrm{C})$, as a result of the formation of crosslinked network structures. FTIR spectra showed the bands at 1646, 1568 and $1654 \mathrm{~cm}^{-1}$ indicated presence of the residual vinyl acetate groups in the PVA chains $(\mathrm{C}=\mathrm{C})$ and the traces of water molecules (bending vibration). These peaks are very weak in spectra of CPVAF due to the more crosslinked hydrogels, than in the CPVA one. The peak around $1095 \mathrm{~cm}^{-1}$ denotes $\mathrm{C}-\mathrm{O}$ stretching of the secondary alcoholic groups [16]. The swelling behaviors of the chemically crosslinked CPVA [20] and CPVAF carriers, $\mathrm{pH}$ (7) at $30^{\circ} \mathrm{C}$ were represented in Figures 2 and 3. The equilibrium swelling rates versus concentrations or the crosslinker ratios relationship is represented in Figure 2. The water uptake is found to decrease for CPVA matrix at increasing the ratio of crosslinker than certain ratio in PVA/E/ $\mathrm{KOH}(100 / 125 / 130)$. This behavior can be explained by the existence of an important crosslinking density which is in accordance with an increase in the crosslinker ratio to optimum swelling properties (9.1), after what, this property decrease (from 9.1 to 6.2) with an increasing in crosslinking density [20]. For CPVA and CPVAF, water uptake increases with increase of time, but the swelling property of CPVA is higher than in CPVAF and this was may suggested for occurring a high crosslinking density in CPVAF resulting in lowering the water uptake. Also, The PVAF hydrogel has the more porous with large size that may be decrease the retention water and, furthermore the presence the oxygen of $\mathrm{CaCO}_{3}$ may form physical bonding with hydroxyl group of PVA leading to a decrease in the penetration of water molecules into the hydrogel network. The thermal analysis of the carriers prepared was used to compare the differences in the polymeric arrangements of the carriers. The thermogravimetry (TG) curves are presented in Figure 4. The CPVA carrier had three main degradation steps: the first was at 189 and $260^{\circ} \mathrm{C}$ and $10 \%$ loss weight was ascribed to the release of volatile compounds, mainly water, which were present in the hydrophilic material. The second stage was between 260 and $400^{\circ} \mathrm{C}$ regarded as the elimination of acetic acid to form a polyene, whereas the third step was between 400 and $485^{\circ} \mathrm{C}$ corresponding to the breakage of the main chain. There was total $82 \%$ lost at last might be attributed to the decomposition of CPVA. TG curves for the CPVAF carrier also showed three consequent stages: The first was come between 160 and $270^{\circ} \mathrm{C}$, and the weight loss was increased to $14 \%$ at $160^{\circ} \mathrm{C}$, indicated an increase in carrier hydrophilicity than in CPVA [3]. The second stage was from 270 to $578.0^{\circ} \mathrm{C}$ and finally, the last stage was from 578.0 and $790.8^{\circ} \mathrm{C}$. There was total $64 \%$ lost at last temperature. Also, the degradation events showed an increase in the thermal stability of the carrier as a result of adding foaming reagent to crosslinking PVA. The DSC curves of the carriers are presented in Figure 5. The sample carriers were included to

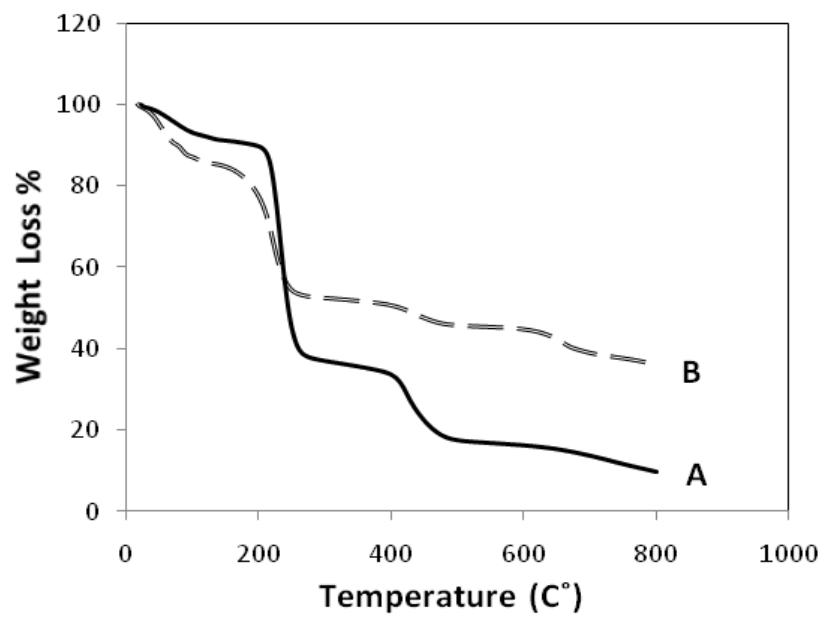

Figure 4: TGA curves of CPVA $(A)$ and CPVA $F(B)$ carriers.

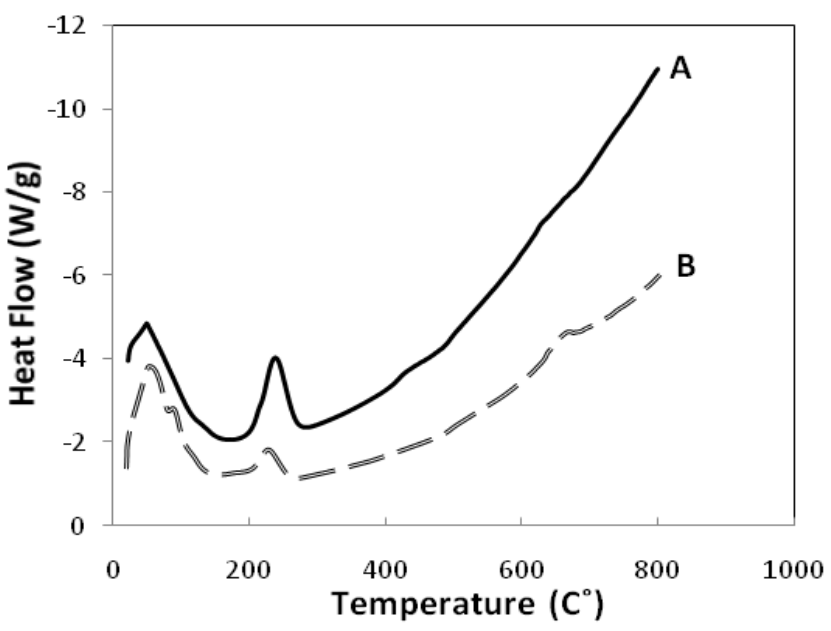

Figure 5: DSC curves of CPVA (A) and CPVA F (B) carriers. 

on Porous PVA Hydrogels or Combining of them with their produced Biosurfactants. J Pet Environ Biotechnol 5: 192. doi:10.4172/21577463.1000192

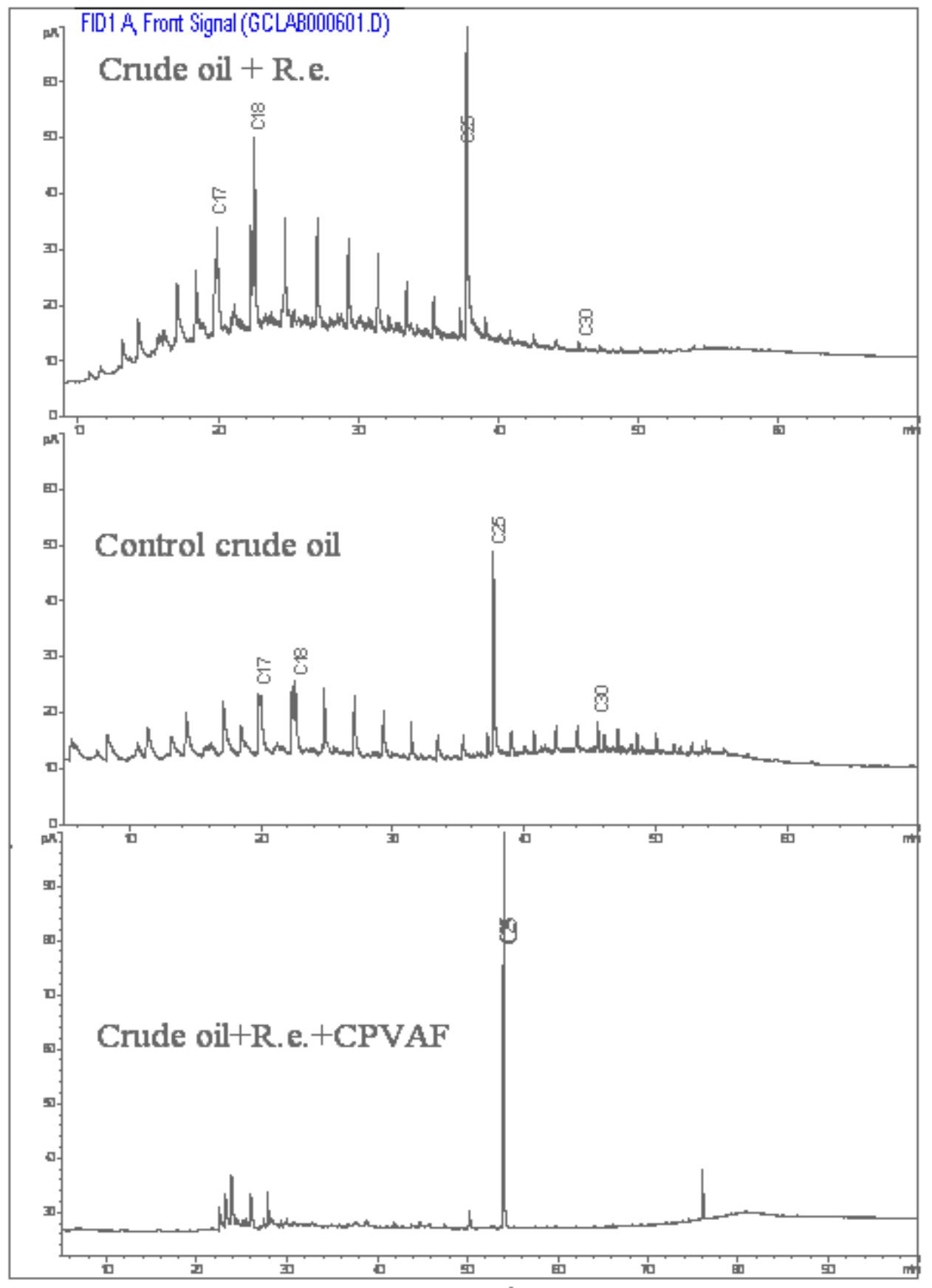

min.

Figure 6: XRD patterns of CPVA $(A)$ and CPVA F (B) carriers.

establish a detailed behavior of the organization of polymeric chains. CPVAF exhibited an endothermic peak at about $223^{\circ} \mathrm{C}$, corresponding to the melting temperature of PVA. The melting temperature was much increased for CPVA. This implied that foaming limited the mobility of the PVA chains. The addition of $\mathrm{CaCO}_{3}$ to the polymeric carrier increased the distance between the chains, regardless of whether the polymer became more crosslinked or branched, which made the organization of PVA in crystalline lattices difficult and formed network structures. The XRD patterns for CPVA (A) and CPVAF (B) carriers were given in Figure 6. The diffraction peak at around $18.4^{\circ} \mathrm{C}$ was a characteristic peak of the crystalline structure of PVA and it was shifted to less $2 \theta$ due to the some deformation in PVA crystallinty as a result of crosslinking. However, its intensity weakened significantly, indicating that the crystalline structure of PVA was changed after the introduction of $\mathrm{CaCO}_{3}$. It may be due to the intermolecular and intramolecular hydrogen bonding between the carbonyl groups in $\mathrm{CaCO}_{3}$ and hydroxyl groups in PVA, which inhibited the formation of crystal structure. This promotes the formation of physically crosslinked PVA hydrogel 
Citation: Abdeen Z, El-Sheshtawy HK, Moustafa YMM (2014) Enhancement of Crude Oil Biodegradation by Immobilizing of different Bacterial Strains on Porous PVA Hydrogels or Combining of them with their produced Biosurfactants. J Pet Environ Biotechnol 5: 192. doi:10.4172/21577463.1000192

Page 6 of 10

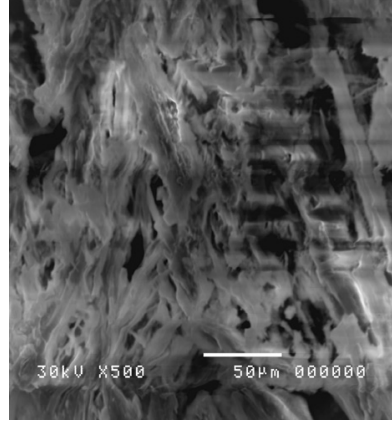

CPVA (A)

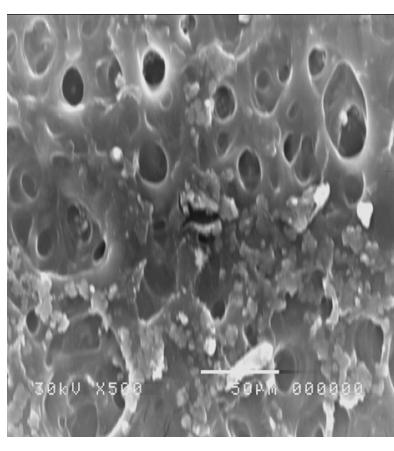

CPVAF (B)
Figure 7: SEM photographs of CPVA (A) and CPVA F (B) carriers

in CPVAF so it becomes more crosslinked structure. Figure 7 shows the surface morphologies of CPVA (A) and CPVAF (B) by scanning electron microscope. It can be seen from Figure 7B that CPVAF were perfectly porous in shape with a rough surface. But, Figure 7A of CPVA shows the less pour in size than in 7B of CPVAF, also, it can be seen that the obtained surfaces of each CPVA $(\mathrm{A})$ and $\mathrm{CPVAF}(\mathrm{B})$ were porous and the pore sizes were heterogeneous because reaction between $\mathrm{CaCO}_{3}$ and $\mathrm{HCl}$ was not uniform throughout the samples. So, CPVA has the more narrow pours, as a result it has the properties are favorable for producing good adsorption capacity. Therefore, an ideal hydrogel carrier should possess a highly porous structure to facilitate the non hindered diffusion of solutes and dissolved gases.

\section{The chemical structure of the biosurfactants produced by different bacterial strains}

Biosurfactants $[9,10]$ are surfactants that are produced extracellularly or as part of the cell membrane by bacteria, yeasts and fungi. They can be potentially as effective with some distinct advantages over the highly used synthetic surfactants including high specificity, biodegradability and biocompatibility. In this work the scope was on certain types of the biosurfactants were produced by different bacterial strains that obtained from contaminated area in our country. The function of these biosurfactant was the increased the solubility of some hydrocarbon compounds so, it enhance the efficiency of microorganisms to degrade a crude oil. It was found that, the biosurfactants are grouped as glycolipids, lipopeptides, phospholipids, fatty acids, neutral lipids, polymeric and particulate compounds [35]. Most of these compounds are either anionic or neutral. Only a few are cationic such as those containing amine groups. The hydrophobic part of the molecule is based on long-chain fatty acids, hydroxy fatty acids or $\alpha$-alkyl- $\beta$-hydroxy fatty acids. The hydrophilic portion can be a carbohydrate, amino acid, cyclic peptide, phosphate, carboxylic acid or alcohol. In this study, the microorganisms (Bacillus licheniformis, Rhodococcus erythropolis and Pseudomonas xanthomarina ) produced three types of the biosurfactants with different structures, cyclic lipopeptide surfactin, phosphatidyl ethanolamine and rhamnolipids respectivly. The structure of the producing biosurfactant was affected by some factors such as type of microorganism, $\mathrm{pH}$, nutrient composition, substrate and temperature used. Where, in our work we choose the conditions that are suitable for the medium of microorganism in our country.

1. The bacterium Bacillus licheniformis has been produced surfactin biosurfactant with a cyclic structure that has affect on enhanced the ability of microorganism to degrade some of hydrocarbon compounds. Where, it increases the solubility of these compounds to increase the capability of microorganism to degrade them.

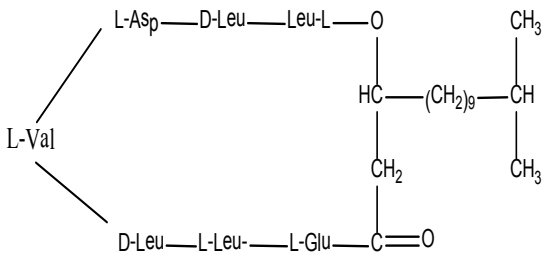

Structure of cyclic lipopeptide surfactin

The Chemical structure of the biosurfactant that produced by Bacillus licheniformis.

2. The bacterium Rhodococcus erythropolis has been produced Phosphatidyl ethanolamine biosurfactant, with cationic structure contained the amino group with positive charges facility the solubility of some of hydrocarbon compounds and their degraded by cells.

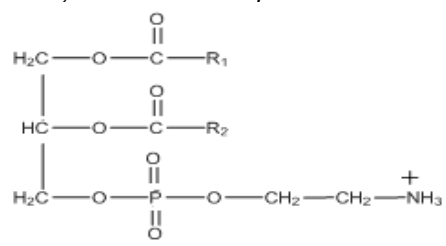

\section{Structure of phosphatidyl ethanolamine}

3. The isolated bacterial strain Pseudomonas xanthomarina has been produced rhamnolipids. From the literature review the Pseudomonas $s p$. produced rhamnolipids biosurfactant rhamnolipids. This strain was first identified using molecular identification and performed by amplifying and sequencing the $16 \mathrm{~S}$ rRNA gene sequences. The results of the identification procedure showed that the isolated bacteria belong to the Pseudomonas xanthomarina KMM 1447. It was found this type of surfactin has hydrophilic groups $(\mathrm{COOH}-$ and $\mathrm{OH}-)$ was lower the surface tension and so, the interfacial tensions at $\mathrm{pH}$, for some hydrocarbon compounds to be degraded by microorganism. Also, it contains a hydrophilic and a hydrophobic domain, may be facilitate the uptake of hydrocarbons into the producing cells

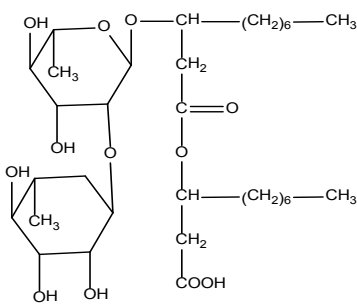

\section{Structure of rhamnolipids}

\section{Application to hydrocarbon biodegradation}

The high cell-retention capacity making CPVA and CPVAF polymers have an effective matrix, where they have the same condition, such as the polymer weight, time of incubation, $\mathrm{pH}$, temperatures and the type of the cell. So, the high cell-retention capacities were expressed about the growth count of cell strains and not the potential of cell to degrade the oil. Where, this was attributed to adapting the cell to utilize some types of components present in oil. As shown at Table 1, the percentage of biodegradation of petroleum hydrocarbon samples, were arranged in this order, R.e. >B.l. > P.x. and Bio2> Bio $3>$ Bio1, with respect to free cells and their produced biosurfactants respectively. 
Citation: Abdeen Z, El-Sheshtawy HK, Moustafa YMM (2014) Enhancement of Crude Oil Biodegradation by Immobilizing of different Bacterial Strains on Porous PVA Hydrogels or Combining of them with their produced Biosurfactants. J Pet Environ Biotechnol 5: 192. doi:10.4172/21577463.1000192

Page 7 of 10

\begin{tabular}{|c|c|c|}
\hline Sample & $\begin{array}{c}\text { Weight of residual } \\
\text { crude oil (g/l) }\end{array}$ & $\begin{array}{c}\text { Percentage } \\
\text { biodegradation }\end{array}$ \\
\hline Control crude oil & 1.0 \\
\hline \multicolumn{2}{|c|}{ B. lichenformis (B.I.) } \\
\hline Crude oil + B.I. & 0.15 & - \\
\hline Crude oil + B. I. + biosurfactant (1) & 0.15 & 85 \\
\hline Crude oil + B. I. + CPVAF & 0.29 & 85 \\
\hline Crude oil + B. I. + CPVA & 0.12 & 71 \\
\hline \multicolumn{2}{|c|}{ Rhodococcus erythropolis (R.e.) } \\
\hline Crude oil + R.e. & 0.14 \\
\hline Crude oil + R.e+ biosurfactant (2) & 0.12 & 86 \\
\hline Crude oil + R.e.+ CPVAF & 0.30 & 88 \\
\hline Crude oil + R.e.+ CPVA & 0.18 & 70 \\
\hline \multicolumn{2}{|c|}{ Pseudomonas xanthomarina (P.x.) } \\
\hline Crude oil + P.x. & 0.17 & 82 \\
\hline Crude oil + P.x.+ biosurfactant (3) & 0.13 & 83 \\
\hline Crude oil + P.x.+ CPVAF & 0.20 & 87 \\
\hline Crude oil + P.x.+ CPVA & 0.10 & 80 \\
\hline
\end{tabular}

Table 1: Percentage biodegradation of petroleum hydrocarbons after treatment with different bacterial strains in presence/ absence of each of biosurfactants and polymers (CPVAF \& CPVA) separately.

${ }^{*}$ percentage biodegradation $=$ Weight of original oil - wt. of residual $/$ wt. of origina oil * 100

The capabilities of B.l. and P.x. to oil degradation were enhanced at immobilized them on CPVA and restricted with CPVAF. No further degradation of petroleum hydrocarbon was observed at immobilized R.e. cell on CPVA and its degradation ability was restricted with CPVAF. The data obtained from the degradation of petroleum hydrocarbon by immobilized cells in all the matrices suggest that the rate of degradation was much higher than that with freely suspended cells. This may be due to a kind of membrane stabilization, which is assumed to be responsible for the cell protection and better degradation rates in the adsorbed cells. However, the fact that the rate of degradation was less in the CPVAF foamed than in CPVA matrices, may be attributed to the slow diffusion of the compounds (oil)into the gel discs. And also, may be as a result of releasing of some cells from gel disc into the medium, because of the large size porosity of the gel matrices.

\section{Growth count of microorganisms}

Three different types of the bacterial strains were used to evaluate their potential for degradation of petroleum hydrocarbons. Their degradation efficiency was improved by each of, adding their producing biosurfactants, and also, by immobilized each of them on two different types of polymers, CPVA and CPVAF. The growth of the different bacterial strains inoculated into the mineral salt medium MSM on the crude oil as a sole carbon and energy sources in presence /absence each of the CPVA and CPVAF gels discs separately and also biosurfactants, were indicated in Table 2 . The count was determined after incubated them at $30^{\circ} \mathrm{C}, 150 \mathrm{rpm}, \mathrm{pH} 7.5$ for 15 days [28]. As shown in Table 2, the bacterial count on crude oil, was increased in these order where, R.e. >P.x.>B.l., but, when adding the biosurfactant (Bio), the order will be change to, P.x.> R.e.>B.l. Where the growth count of bacterial P.X. enhanced with adding its producing biosurfactant 3(Bio3), and also, when immobilizing it on each of CPVA and CPVAF. On other hand the growth count of bacterium B.l. and R.e. were inhibited or restricted by immobilizing the on the polymer CPVAF, but enhanced with CPVA in case bacteria B.l. and somewhat restricted with R.e.

\section{The degradation of paraffins compounds}

The residual of the n-paraffin after biodegradation was identified using GC as shown in Table 3. The UCM\% was high (84.68) in control sample than of the most residual samples, suggesting that the control sample we obtained was exposed to the most chronic oil pollution. Also, was noticed that the most remaining percentages of the n-paraffin after biodegradation are higher than its of the crude oil control, suggesting that occurring more biodegradation for UCM than that for paraffin compounds. The results revealed that the bacterium, Bacillus lichneformis ATCC 10716 (B.1.), Rhodococcus erythropolis ATCC 13260 (R.e.) and Pseudomonas xanthomarina KMM 1447 strains, that, were isolated from a biological waste-water, have the capability to utilizing paraffins as the sole source of carbon and energy and this capability was increased in this order, R.e.> P.x.>B.l. This is attributed to their efficiencies to degrade the non polar compounds (paraffin), but, the bacterial (B.l.) has the best degradation for unresolved complex mixture (UCM) with comparison with others bacterium. This ability increase when it was immobilized on each of CPVAF and CPVA polymers. On the other hand the paraffins biodegradations percentage, by R.e. and P.x. microorganisms were enhanced at adding to them their produced biosurfactants (Bio2 and Bio3) (19.05\%, 19.77\%, respectively). These percentages degradation increase at immobilized these cells on CPVA, but when R.e. was immobilized on CPVAF, the complete degradation for the paraffins and UCM, was determined to indicating that this polymer foaming type enhanced the biodegradation efficiency of R.e. to degrade completely the paraffin from $\mathrm{C}_{9}$ to $\mathrm{C}_{39}$ and UCM. As we can see, the macro porous CPVAF carrier could provide sufficient space for microbial growth. Also, the polarity of the produced biosurfactants by B.l., R.e. and P.x. was increased in this direction, (Bio $1<$ Bio $2<$ Bio 3 ).

\section{The degradation of PAHs}

The brief identification and quantification of PAHs in the investigated of the crude oil remained after biodegradation and the corresponding control sample using HPLC, were shown in Table 4. The HPLC results showed that, the presence of 2,3 and 4,5,6- member rings of PAHs. In the control sample the percentage concentration of 4 -member rings is higher than that of the 5-member rings of PAHs. The results showed that the freely suspended Rhodococcus erythropolis (R.e.) can utilize 5-member rings of PAHs completely and degraded them to 3 and 4 -member rings of PAHs, Table 4. So, there no remaining of 5-member rings of PAHs was detected. On the other hand, the efficiency of Pseudomonas xanthomarina to degrade the 5-member rings of PAHs is less than that of the R.e. but, higher than that of B.l.,

\begin{tabular}{|l|c|}
\hline Sample & CFU/ml \\
\hline B. lichemfomis (B.I.) & $2.5 \times 10^{7}$ \\
\hline Crude oil + B.I. & $3.5 \times 10^{7}$ \\
\hline Crude oil + B. I. + biosurfactant(1) & $1.3 \times 10^{7}$ \\
\hline Crude oil + B. I. + CPVAF & $5 \times 10^{7}$ \\
\hline Crude oil + B. I. + CPVA & \\
\hline Rhodococcus erythropolis (R.e.) & $5.6 \times 10^{7}$ \\
\hline Crude oil + R.e. & $7 \times 10^{7}$ \\
\hline Crude oil + R.e+ biosurfactant(2) & $2 \times 10^{7}$ \\
\hline Crude oil + R.e.+ CPVAF & $5 \times 10^{7}$ \\
\hline Crude oil + R.e.+ CPVA & \\
\hline Pseudomonas xanthomarina ( P.x. ) & $4 \times 10^{7}$ \\
\hline Crude oil + P.x. & $9 \times 10^{7}$ \\
\hline Crude oil + P.x. + biosurfactant (3) & $7 \times 10^{7}$ \\
\hline Crude oil + P.x. + CPVAF & $8 \times 10^{7}$ \\
\hline Crude oil + P.x. + CPVA & \\
\hline
\end{tabular}

Table 2: Growth count of different bacterial strains, in the presence / absence of each of biosurfactants and polymers (CPVAF \& CPVA) separately. 
Citation: Abdeen Z, El-Sheshtawy HK, Moustafa YMM (2014) Enhancement of Crude Oil Biodegradation by Immobilizing of different Bacterial Strains on Porous PVA Hydrogels or Combining of them with their produced Biosurfactants. J Pet Environ Biotechnol 5: 192. doi:10.4172/21577463.1000192

Page 8 of 10

\begin{tabular}{|c|c|c|c|c|c|c|c|}
\hline \multirow[b]{2}{*}{ Sample } & \multicolumn{7}{|c|}{ Percentage residual of paraffins after bio-treatment } \\
\hline & $\mathrm{C}_{9-20}$ & $\mathrm{C}_{21-30}$ & $\mathrm{C}_{31-39}$ & $\begin{array}{l}\text { Total area } \\
\text { paraffins }\end{array}$ & $\begin{array}{c}\text { Total area } \\
\text { sample }\end{array}$ & (\%) paraffins & (\%) UCM \\
\hline Control crude oil & 78.20 & 17.6 & 4.2 & 3477.34 & $2.27 \times 10^{4}$ & 15.32 & 84.68 \\
\hline \multicolumn{8}{|c|}{ B. lichenformis (B.I.) } \\
\hline Crude oil + B.I. & 18.04 & 74.47 & 7.49 & $9.54 \times 10^{4}$ & $4.14 \times 10^{5}$ & 23.04 & 76.96 \\
\hline Crude oil+B. I.+biosurf.(1) & 22.74 & 68.19 & 9.07 & $6.24 \times 10^{4}$ & $2.94 \times 10^{5}$ & 21.22 & 78.78 \\
\hline Crude oil +B. I +CPVAF & 30.61 & 68.72 & 0.67 & 6597.87 & $1.87 \times 10^{4}$ & 35.28 & 64.72 \\
\hline Crude oil+B. I + CPVA & 81.67 & 16.37 & 1.96 & 1871.78 & 5829.88 & 32.11 & 67.89 \\
\hline \multicolumn{8}{|c|}{ Rhodococcus erythropolis (R.e.) } \\
\hline Crude oil + R.e. & 62.26 & 36.66 & 1.08 & 2388.68 & $2.013 \times 10^{4}$ & 11.87 & 88.13 \\
\hline Crude oil+R.e.+biosurf.(2) & 31.35 & 51.06 & 17.59 & $7.79 \times 10^{4}$ & $4.09 \times 10^{5}$ & 19.05 & 80.95 \\
\hline Crude oil+R.e.+CPVAF & 0 & 0 & 0 & 0 & 0 & 0 & 0 \\
\hline Crude oil + R.e.+CPVA & 20.93 & 69.67 & 9.4 & $4 \times 10^{4}$ & $1.85 \times 10^{5}$ & 21.62 & 78.38 \\
\hline \multicolumn{8}{|c|}{ Pseudomonas xanthomarina (P.x.) } \\
\hline Crude oil + P.x. & 38.42 & 46.75 & 14.83 & $2.26 \times 10^{4}$ & $1.9 \times 10^{5}$ & 11.89 & 88.11 \\
\hline Crude oil+P.x.+biosurf.(3) & 39.9 & 50.33 & 9.77 & $7.83 \times 10^{4}$ & $3.96 \times 10^{5}$ & 19.77 & 80.23 \\
\hline Crude oil+P.x.+ CPVAF & 49 & 48 & 3 & 2458.47 & $1.3 \times 10^{4}$ & 18.91 & 81.9 \\
\hline Crude oil + P.x.+ CPVA & 35.98 & 53.55 & 10.47 & $7.62 \times 10^{4}$ & $3.63 \times 10^{5}$ & 20.99 & 79.01 \\
\hline
\end{tabular}

Table 3: Distribution of carbon number in gas chromatogram of residual crude oil after treatment by different bacterial strains in presence/ absence of each of biosurfactants and polymers (CPVAF \& CPVA) separately.

\begin{tabular}{|c|c|c|c|c|c|c|c|c|c|c|c|c|c|c|c|}
\hline \multirow{2}{*}{ Sample } & \multicolumn{6}{|c|}{ 2-member rings of polyaromatics } & \multicolumn{4}{|c|}{ 3-member rings of polyaromatics } & \multicolumn{5}{|c|}{ 4-member rings of polyaromatics } \\
\hline & \begin{tabular}{|l|l} 
Naph & $A$ \\
\end{tabular} & Acena & Acer & naph & Fluo To & Total Conc. (\%) & Ph. & Anth. & & otal conc. $(\%)$ & Flu & Pyr & B(a) anth & $\mathrm{Ch}$ & Total conc. (\%) \\
\hline Control crude oil & 0 & 0 & c & 0 & 0 & 0 & 0 & 0 & & 0 & 67.77 & 0 & 0 & 2.67 & 70.44 \\
\hline \multicolumn{16}{|c|}{ B. licheniformis (B.I.) } \\
\hline Control crude oil + B.I. & 18.92 & 22.87 & \multicolumn{2}{|c|}{0} & 0 & 41.77 & 0 & 0 & & 0 & 4.12 & 0 & 1.15 & 9.03 & 14.3 \\
\hline $\begin{array}{l}\text { Control crude oil + B.I. + } \\
\text { biosurfactant (1) }\end{array}$ & 9.96 & 0 & \multicolumn{2}{|c|}{0} & 0 & 9.96 & 0 & 0 & & 0 & 6.13 & 0 & 2.42 & 3.19 & 11.74 \\
\hline Control crude oil + B.I. + CPVAF & 0 & 0 & \multicolumn{2}{|c|}{0} & 0 & 0 & 0 & 0 & & 0 & 69.24 & 0 & 0 & 0 & 69.24 \\
\hline Control crude oil + B.I. + CPVA & 0 & 87.00 & \multicolumn{2}{|c|}{0.81} & 0 & 87.81 & 1.39 & 0 & & 1.39 & 0.10 & 0 & 0.66 & 0 & 0.76 \\
\hline \multicolumn{16}{|c|}{ Rhodococcus erythropolis (R.e.) } \\
\hline Crude oil + R.e. & 0 & 0 & \multicolumn{2}{|c|}{0} & 0 & 0 & 13.79 & 0 & & 13.79 & 86.21 & 0 & 0 & 0 & 86.21 \\
\hline Crude oil + R.e. + biosurfactant (2) & 0 & 0 & \multicolumn{2}{|c|}{0} & 0 & 0 & 0 & 20.28 & & 20.28 & 5.7 & 0 & 2.13 & 0 & 7.83 \\
\hline Crude oil + R.e. + CPVAF & 0 & 0 & \multicolumn{2}{|c|}{0} & 0 & 0 & 3.56 & 10.98 & & 14.54 & 25.76 & 0 & 1.84 & 0 & 27.60 \\
\hline Crude oil + R.e. + CPVA & 6.42 & 7.63 & \multicolumn{2}{|c|}{0} & 0 & 14.05 & 5.84 & 3.69 & & 9.53 & 0.58 & 0.99 & 3.99 & 37.76 & 43.32 \\
\hline \multicolumn{16}{|c|}{ Psuedomonas xanthomarina (P.x.) } \\
\hline Crude oil + P.x. & $29.57 \quad 2$ & 20.56 & \multicolumn{2}{|c|}{0} & 9.42 & 59.55 & 0.14 & 0.22 & & 0.36 & 2.68 & 20.87 & 3.68 & 0.10 & 27.33 \\
\hline Crude oil + P.x. + biosurfactant (3) & 0 & 85.83 & \multicolumn{2}{|c|}{0} & 0 & 85.83 & 2.15 & 0 & & 2.15 & 0 & 0 & 1.09 & 0 & 1.09 \\
\hline Crude oil + P.x. + CPVAF & 0 & 0 & \multicolumn{2}{|c|}{0} & 0 & 0 & 0 & 0 & & 0 & 52.46 & 0 & 0 & 0 & 52.46 \\
\hline Crude oil + P.x. + CPVA & 6.08 & 1.12 & \multicolumn{2}{|c|}{0} & 0 & 7.2 & 1.08 & 0 & & 1.08 & 0 & 7.20 & 29.55 & 17.68 & 54.43 \\
\hline \multirow{2}{*}{ Sample } & \multicolumn{9}{|c|}{ 5-member rings of polyaromatics } & \multicolumn{6}{|c|}{ 6-member rings of polyaromatics } \\
\hline & \multicolumn{3}{|c|}{$B(b)$ flu $B(k)$ flu } & \multicolumn{2}{|c|}{ B (a) pyrene } & e Dib (a,h)anth & Total & lanc. & & B $(g, h, i)$ peryl & lene I & Indeno( & $(1,2,3,-c d)$ & pyrene & Total conc. (\%) \\
\hline Control crude oil & 0 & 18 & .77 & & 10.79 & 0 & & 29.56 & & 0 & & & 0 & & 0 \\
\hline & & & & & & B. lichenifor & rmis $(B$ & B.I.) & & & & & & & \\
\hline Control crude oil + B.I. & 0 & & .29 & & 30.76 & 0.90 & & 42.95 & & 0 & & & 0.98 & & 0.98 \\
\hline $\begin{array}{l}\text { Control crude oil + B.I. + } \\
\text { biosurfactant (I) }\end{array}$ & 0 & & .38 & & 39.89 & 17.06 & & 77.33 & & 0.68 & & & 0.29 & & 0.97 \\
\hline Control crude oil + B.I. + CPVAF & 0 & 30 & .76 & & 0 & 0 & & 30.76 & & 0 & & & 0 & & 0 \\
\hline & & & & & & Rhodococcus ery & ythropo & olis (R.e. & & & & & & & \\
\hline Crude oil + R.e. & 0 & & 0 & & 0 & 0 & & 0 & & 0 & & & 0 & & 0 \\
\hline Crude oil + R.e. + biosurfactant (2) & 4.44 & & 89 & & 30.56 & 0 & & 71.89 & & 0 & & & 0 & & 0 \\
\hline Crude oil + R.e. + CPVAF & 6.36 & & 82 & & 0 & 48.68 & & 57.86 & & 0 & & & 0 & & 0 \\
\hline Crude oil + R.e. + CPVA & 0 & & .1 & & 31.86 & 0.66 & & 32.62 & & 0.33 & & & 0.15 & & 0.48 \\
\hline & & & & & & seudomonas xan & nthoma & arina $(P . x$ & & & & & & & \\
\hline Crude oil + P.x. & 2.6 & & 23 & & 4.83 & 0.99 & & 11.65 & & 0.60 & & & 0.49 & & 1.09 \\
\hline Crude oil + P.x. + biosurfactant (3) & 7.92 & & 73 & & 0.28 & 0 & & 10.93 & & 0 & & & 0 & & 0 \\
\hline Crude oil + P.x. + CPVAF & 17.57 & 29. & .97 & & 0 & 0 & & 47.54 & & 0 & & & 0 & & 0 \\
\hline Crude oil + P.x. + CPVA & 0 & & 69 & & 36.60 & 0 & & 37.29 & & 0 & & & 0 & & 0 \\
\hline
\end{tabular}

Table 4: HPLC analysis of Polynuclar aromatics hydrocarbons distribution in crude oil after treatment by different bacterial strains, in presence/absence of each of biosurfactant and polymers (CPVAF \& CPVA) separately. 
Citation: Abdeen Z, El-Sheshtawy HK, Moustafa YMM (2014) Enhancement of Crude Oil Biodegradation by Immobilizing of different Bacterial Strains on Porous PVA Hydrogels or Combining of them with their produced Biosurfactants. J Pet Environ Biotechnol 5: 192. doi:10.4172/21577463.1000192

where, the percentage concentration of the 5-member rings of PAHs is increase in presence B.l. than that in control sample. This result may be attributed to ability of this microorganism (B.l.) to degrade the 4 -member rings of PAHs that has certain polarity to lower 2-member rings of PAHs, that may be combined with each others to form the 5 -member rings of PAHs. So, the degradation arrangement of polar compound by microorganism increase in this direction, R.e. > P.x.> B.l. The efficient of these microorganisms were enhanced by immobilized them on different types of polymers (CPVA and CPVAF) or by adding their produced biosurfactants to them. Biosurfactants accumulated at interfaces, forming micelles that lowered the surface tension and thereby enhanced the solubility of poorly soluble compounds in water [36]. So, it was shown (Table 4), that the degradation efficiency of the B.l. to degrade the low polar compound (4-member rings PAHs), was enhanced by adding its produced biosurfactant (Bio1) to it. But its potential to degrade the 5-member rings of PAHs, is not recorded only; furthermore the percentage concentration of these compounds increased $(77.33 \%)$ than with the B.l. alone. Also, this behavior of biodegradation was noticed with adding the produced biosurfactant (Bio2) to R.e. strain, resulting in restricted the utilizing of this bacteria for the 5 -member rings of PAHs. It was found that, the combination of P.x. with its biosurfactant 3 (Bio3), enhanced its capability to degrade the 5-member rings of PAHs to 2 -member rings of PAHs. Moreover, this combination made them to utilize on the 4-member rings of PAHs, where, they were superior in removing these compounds to residue of $1.09 \%$. The enhancement or restricting of these biosurfactants towards the degradation capabilities of these strains to degrade the crude oil may be attributed to their structures. So, due to the structure of Bio3 contains many hydrophilic groups act as adsorbance sites for crude oil and also, can react with polar compounds than others (paraffin) resulting in degradation these compounds. At immobilizing the strain B.l. on each of, CPVA and CPVAF polymers, it was found that, with CPVAF no significant degrading of 4 and 5-member rings of PAHs, was observed. Although, the efficient of this strain enhanced when it was immobilized on CPVA to remove these PAHs and the remains was 0.76 and $10.04 \%$ of each 4 and 5-member rings of PAHs respectively. This immobilizing method was enhanced the potential of this strain to degrade the 4 and 5-member rings of PAHs to 2-member rings of PAHs. But, this enhancement biodegradation proper decrease at immobilizing the R.e. strain on CPVA to degrade the 4 and 5-member rings of PAHs to 2 and 3-member rings of PAHs with the concentration of 43.32 and $32.62 \%$ respectively. However, this potential of this strain to degrade the 4 -member rings to the 3 -member rings was increased with CPVAF polymer. It was noticed that, the residual of the 5 -member rings increase more than that in the control sample, where, it may be as a result of the combination of low polar compounds. Also, this biodegradation behavior was occurred at immobilizing the P.x. strain on these polymers.

This study revealed that the more efficient degradation of fluoranthen (Flu) (4 -member rings) was completely by using P.x. cell combined with its biosurfactant or immobilized it on CPVA polymer. The high removal was occurred by freely P.x. and immobilized each of B.l. and R.e. cells on CPVA polymer or combined each of them with their produced biosurfactants. Also, chrysene (Chr) was removed completely by freely R.e. cell or by immobilized each of B.l., R.e. and P.x. cells on CPVAF and also, B.l. on CPVA. The superior removal was recorded by freely P.x. The complete degradation of Benzo [a] Pyrene (BaP) (5-member rings) was observed by immobilized each of B.l., R.e. and P.x. cells on CPVAF polymer and by freely R.e. cell. But, the superior degradation, was occurred by combination of P.x with its produced biosurfactant (Bio3), where, it being amphipathic molecules of the biosurfactant (Bio3) with a hydrophilic and a hydrophobic domain, may be facilitate the uptake of hydrocarbons into cells. It was observed that, the complete removal of Benzo [K] fluranthene (5-member rings) was only, by freely R.e cell and the good degradation was occurred by immobilized each of B.l., R.e. and P.x. cells on CPVA polymer and also, by immobilized R.e. cell on CPVAF polymer. As well, it was revealed the good degradation of Benzo $[\mathrm{K}]$ fluranthene by combined each of R.e.and P.x. cells with their produced biosurfactants and by freely P.x cell. Surfactants can increase the surface area of hydrophobic materials, in water environment, thereby increasing their water solubility. Hence, the presence of surfactants may increase the efficiency of microbial to degrade the pollutants. It was revealed that the physicochemical stability of the PVA carrier was increased and the hydroxyl groups created a hydrophilic micro-environment for the metabolism of the immobilized microorganisms. Thus there is a potential for the development of microbial technology for the treatment of waste water containing aromatic hydrocarbons.

\section{Conclusion}

The immobilization methods make the cells stay alive for a long time in the immobilized stage when the conditions are optimal. Bioremediation using immobilized cells has been widely investigated for numerous toxic chemicals such as paraffins and aromatic hydrocarbons. In the present study, the CPVA and CPVAF macroporous carriers were prepared based on PVA with a pore-forming agent (calcium carbonate) with respect for CPVAF and each of was crosslinked with epichlorohydrin. Calcium carbonates as foaming agent has lower toxicity to yeast cells. The CPVA and CPVAF hydrogel discs were showed; the higher stability in water but CPVA has greater biological activity than CPVAF hydrogels that has more crosslinked structure. The CPVA and CPVAF carriers can serve as a suitable material for immobilized microorganisms, as they have the better chemical and thermal stability. For immobilization of bacteria, the CPVA carrier supports the higher biomass density and microbial activity yield than the CPVAF carrier. The maximum growth count was for P.x. strain immobilized on CPVA $\left(8 \times 10^{7} \mathrm{CFU} / \mathrm{ml}\right)$ and also at, presence of the Bio 3 with P.x $\left(9 \times 10^{7} \mathrm{CFU} / \mathrm{ml}\right)$. The higher growth count may attribute to the greater mass transfer of the substrate (and oxygen) between the bulk solution and the immobilized on CPVA carrier or combined with Bio 3 microorganisms. The rate of degradation of oil by immobilized cells in various matrices is compared with that by freely suspended cells, and combined with their produced biosurfactants with regards to oil degrading capacity at various initial oil concentrations. The longevity of the hydrocarbons degrading activity was by immobilized cells and by presence of biosurfactant with cells. These preparation methods of CPVA, CPVAF and biosurfactants were inexpensive, low in toxicity, and easily performed; they can serve as a promising and economical technique for immobilizing microorganisms. In addition, may be after being modified, the CPVA and CPVAF could serve as valuable carriers or supports in the biotechnology and biochemistry fields.

\section{Acknowledgment}

We are grateful for the grant obtained from the members in Central Analytical Lab, Department of Processes Development and Petrochemicals Department, Egyptian Petroleum Research Institute (EPRI).

\section{References}

1. RR Colwell, JD Walker, JJ Cooney (1977) Ecological aspects of microbial degradation of petroleum in the marine environment. CRC Criti Rev Microbiol 5: $423-445$. 
Citation: Abdeen Z, El-Sheshtawy HK, Moustafa YMM (2014) Enhancement of Crude Oil Biodegradation by Immobilizing of different Bacterial Strains on Porous PVA Hydrogels or Combining of them with their produced Biosurfactants. J Pet Environ Biotechnol 5: 192. doi:10.4172/21577463.1000192

Page 10 of 10

2. YM Moustafa (2004) Contamination by polycyclic aromatic hydrocarbons in some Egyptian Mediterranean coasts. Journal of Biosciences Biotechnology Research Asia 2: 15-24.

3. EJ Baum (1978) in: HV Gelboin, POP Ts'o (Eds.), Polycyclic Hydrocarbons and Cancer, Environment Chemistry and Metabolism, Vol. 1, Academic Press, New York, San Francisco, London.

4. KSM Rahman, Rahman JT, Lakshmanaperumalsamy P, Banat IM (2002) Towards Efficient Crude Oil Degradation by a Mixed Bacterial Consortium. Bioresour Technol 85: 257-261.

5. Shuttleworth KL, Cerniglia CE (1995) Environmental aspects of PAH biodegradation. Appl Biochem Biotechnol 54: 291-302.

6. Wattiau P, in: S.N. Agathos, W. Reineke (2002) (Eds.), Biotechnology for the Environment: Strategy and Fundamentals, Kluwer Academic Publishers. Netherlands.

7. Larkin MJ, Kulakov LA, Allen CCR (2005) Environ Biotechnol, Poland.

8. Georgiou G, Lin SC, Sharma MM (1992) Surface-active compounds from microorganisms. Biotechnology 10: 60-65.

9. Morikawa M, Hirata Y, Imanaka T (2000) A Study on the structure-function relationship of lipopeptides biosurfactants. Biochimica et Biophysica Acta 1488: 211-218.

10. Benincasa M, Contiero J, Manresa MA, Moraes IO (2002) Rhamnolipid production by Pseudomonas aeruginosa LBI growing on soap stock as the sole carbon source. Journal of Food Engineering 54: 283-288.

11. IM Banat (1995) Biosurfactants production and possible uses in microbia enhanced oil recovery and oil pollution remediation: A Review Bio Techn 51: $1-12$

12. Kim SH, Lim EJ, Lee SO, Lee JD, Lee TH (2000) Purification and characterization of biosurfactants from Nocardia sp. L-417. Biotechnol Appl Biochem 31: 249-253.

13. Rosiak JM, Janik I, Kadlubowski S, Kozicki M (2003) Nano-, micro- and macroscopic hydrogels synthesized by radiation technique. Nucl Instr And Meth B 208: 325-330.

14. Abdeen Z (2005) Ph.D. Thesis, Preparations and Applications of Some Friendly Environmental Compounds Ain-Shams University, Cairo.

15. Abdeen Z (2011) Swelling and Re-swelling Characteristics of Cross-linked Poly (vinyl alcohol)/Chitosan Hydrogel Film. J Dis Sci Techn 32: 1337-1344.

16. AL-Sabagh AM, Abdeen Z (2010) Preparation and Characterization of Hydrogel based on Poly Vinyl Alcohol Crosslinked by Different Crosslinker Used to Dry Organic Solvents. J Polym Environ 18: 576-583.

17. Ratner BD, Bryant SJ (2004) Biomaterials: where we have been and where we are going. Annu Rev Biomed Eng 6: 41-75.

18. Figueiredo KCS, Alves TLM, Borges CP (2009) Poly(vinyl alcohol) films crosslinked by glutaraldehyde under mild conditions. J Appl Polym Sci 111: 3074-3080.

19. Bezbradica D, Obradovicb B, Leskosek-Cukalovic I, Bugarski B, Nedovic V (2007) Immobilization of yeast cells in PVA particles for beer fermentation. Process Biochem 42: 1348-1351.

20. Sanchez-Chaves M, Ruiz C, Cerrada ML, Fernandez-Garcia M (2008) Novel glycopolymerscontaining aminosaccharide pendant groups by chemical modification of ethylene-vinyl alcohol copolymers. Polym 49: 2801-2807.

21. De Borba BM, Urbansky ET (2002) Performance of poly (vinyl alcohol) gel columns on the ion chromatographic determination of perchlorate in fertilizers. J Environ Monit 4: 149-155.
22. Li YF, Bai X, Men XH, Yang LQ (2008) Macroreticular carrier based on poly(vinyl alcohol) foam and its application, China.

23. Abd El-hady A, Abd El-Rehim HA (2004) Production of Prednisolone by Pseudomonas oleovorans Cells Incorporated Into PVP/PEO Radiation Crosslinked Hydrogels. J Biomed Biotechnol 4: 219-226.

24. Karel SF, Libik B, Roberstson CR (1985) The immobilization of whole cells: Engineering principles. Chem Eng Sci 40: 1321.

25. Kuyukina MS, Ivshina IB, Yu Gavrin A, Podorozhko EA, Lozinsky VI, et al (2005) Immobilization of hydrocarbon-oxidizing bacteria in poly(vinyl alcohol) cryogels hydrophobized using a biosurfactant. J Microbiol Meth 65: 596-603.

26. Haghighat S, Akhavan A, Assadi MM, Pasdar SH (2008) Ability of indigenous Bacillus licheniformis and Bacillus subtilis in microbial EOR. Int J Environ Sc Tech 5: 385-390.

27. Haddad $\mathrm{NI}$, Wang Ji, Bozhong $\mathrm{Mu}$ (2008) Isolation and characterization of biosurfactant producing strain, Brevibacilibrevis HOB1 J Ind Microbiol Biotechnol 35: 1597-1604.

28. El-Sheshtawy HS (2011) Biosynthesis and evaluation of some biosurfactants potentially active in remediation of petroleum pollution Ph.D. Thesis. Maicrobiol. Dept. Faculty of science. Cairo University

29. Benson HJ (1995) Microbiological applications: A laboratory manual genera microbiology, (6 $6^{\text {th }}$ Edition), Wmc. Brown Company Publshers, Pubuque Lowa USA.

30. Institute of Petroleum (1995) Characterization of pollutants-High resolution gas chromatography method. IP standard methods for analysis and testing of petroleum and related products, The Energy Institute.

31. Ferrus $R$, Pages $P$ (1977) Determination of the water retention value (WRV) of chitosan, Cell. Chem. Technol.

32. Aboustate MA, Moustafa YM (2005) Biodegradation of polycyclic Aromatic Hydrocarbons from Petroleum Crude Oils, Egyptian Journal of Biotechnology.

33. Lal BHM, Khanna S (1996) Degradation of crude oil by Acinetobactercalcoaceticusand Alcaligenesodorans. J Appl Bacteriol 81: 355362.

34. Hatch AC, Burton GA (1999) Photo-induced Toxicity of PAHs Hyalella Azteca and Chironomus Tentans: Effect of Mixures and Behavior, Environmental Pollution 106: 57-167.

35. Biermann M, Lange F, Piorr R, Ploog U, Rutzen H, et al. (1987) In: Falbe, J. (Ed.), Surfactants in Consumer Products, Theory, Technology and Application.

36. Kuiper I, Ellen L, Lagendijk RP, Jeremy PD, Gerda EML, et al. (2004 Characterization of two Pseudomonas putida lipopeptide biosurfactants, putisolvin I and II, which inhibit biofilm formation and break down existing biofilms. Molecul Microb 51: 97-113. 